Notes

\title{
APPLICATION OF THE DOCTRINE OF EQUIVALENTS TO MEANS PLUS FUNCTION CLAIMS: WMS GAMING INC. V. INTERNATIONAL GAME TECHNOLOGY
}

\author{
JOHN N. KANDARA
}

\section{INTRODUCTION}

In recent years, courts apparently concerned that the public's level of access to technology may be decreasing have sought to limit the scope of patent claim coverage on several fronts. Generally speaking, recent decisions by the U.S. Supreme Court and the U.S. Court of Appeals for the Federal Circuit have encouraged narrower, more literal readings of patent claim language, and thus less overall protection for patent holders, in such areas as the use of functional expressions in combination claims, ${ }^{1}$ the availability and proper application of the doctrine of equivalents in patent infringement cases, ${ }^{2}$ and the interpretation of words of ordinary usage within the patent claims. ${ }^{3}$ The trend has been particularly obvious where the doctrine of equivalents ${ }^{4}$ is applied to patent claims written in means

Copyright $(\underset{2}{2} 2000$ by John N. Kandara.

1. See, e.g., O.I. Corp. v. Tekmar Co., 115 F.3d 1576, 1583 (Fed. Cir. 1997) (holding that "an element in a combination method or process claim may be recited as a step for performing a specified function without the recital of acts in support of the function").

2. See, e.g., Warner-Jenkinson Co. v. Hilton Davis Chem. Co., 520 U.S. 17, $28-29$ (1997) ("[T]he doctrine of equivalents must be applied to individual elements of the claim, not to the invention as a whole.").

3. See, e.g., Toro Co. v. White Consol. Indus., Inc., 199 F.3d 1295, 1299 (Fed. Cir. 1999) ("Determining the limits of a patent claim requires understanding its terms in the context in which they were used by the inventor, considered by the examiner, and understood in the field of the invention.").

4. See discussion infra Part I.C. Briefly, the doctrine of equivalents holds that a patent is infringed not only when an accused device falls within a strict literal reading of the patent claims but also when the accused device, though not literally within the patent claims, is only 
plus function format, ${ }^{5}$ with the courts eliminating availability of the doctrine of equivalents for these claims. ${ }^{6}$

A recent high-stakes contest involving a patent for slot machines seems to herald a reversal of this trend. In WMS Gaming Inc. $v$. International Game Technology, a panel of the U.S. Court of Appeals for the Federal Circuit held that a patent claim written in means plus function language, although not literally infringed, had been infringed under the doctrine of equivalents. ${ }^{8}$ In so doing, the court held for the first time that the doctrine of equivalents can apply to a means plus function claim where an element of an accused device does not perform identically but only substantially the same function as that claimed in the patent. ${ }^{9}$ By allowing the application of the doctrine of equivalents in this case, the court not only resolved a previously open question of law ${ }^{10}$ and halted the trend eliminating availability of the doctrine of equivalents for claims written in the means plus function format but also endorsed a broader, less literal interpretation of patent claim language.

This Note will analyze the Federal Circuit's evolving jurisprudence on the application of the doctrine of equivalents to patent claims written in the means plus function format. Part I describes the background of U.S. patent law relevant to the case, particularly the statutory authorization for means plus function claims, the judicially created doctrine of equivalents, and how courts

insubstantially different from what is claimed in the patent.

5. See discussion infra Part I.B. Means plus function claims allow an inventor to claim an element of his invention by describing the result it accomplishes or the function it serves, rather than by describing the structure used to accomplish that result.

6. The trend is illustrated by cases such as Warner-Jenkinson Co. v. Hilton Davis Chem. Co., 520 U.S. 17 (1997), and Chiuminatta Concrete Concepts, Inc. v. Cardinal Indus., Inc., 145 F.3d 1303 (Fed. Cir. 1998). Warner-Jenkinson is discussed infra at Part I.C, and Chiuminatta is discussed infra at Part I.D.

7. 184 F.3d 1339 (Fed. Cir. 1999).

8. See id. at 1353-54.

9. Although the Federal Circuit had previously made a similar statement in dicta, see AlSite Corp. v. VSI Int'1, Inc., 174 F.3d 1308, 1320-21 (Fed. Cir. 1999) (“[U]nder § 112, II 6, the accused device must perform the identical function as recited in the claim element while the doctrine of equivalents may be satisfied when the function performed by the accused device is only substantially the same."), there was no particular reason to assume that the court would not instead continue to narrow availability of the doctrine of equivalents. See also Dawn Equip. Co. v. Kentucky Farms Inc., 140 F.3d 1009, 1022 n.8 (Plager, J., additional views) (reserving the question of "whether a $\S 112$, If 6 claim limitation is limited to the 'specified function,' or . . can also encompass an equivalent function under the doctrine of equivalents").

10. See Dawn Equip. Co., 140 F.3d at 1022 n.8 (Plager, J., additional views) (resolving the application of the doctrine of equivalents to a means plus function claim). 
have applied the doctrine of equivalents to claims written in the means plus function format. Part II discusses the facts and holding of the WMS Gaming case, and Part III summarizes the Federal Circuit's analysis of the proper application of the doctrine of equivalents to a means plus function claim. Part IV argues that the decision reached by the Federal Circuit on how the doctrine of equivalents should be applied in cases where there is substantial similarity but no identicality of function between an accused device and a patent claim strikes an appropriate balance between protecting patent holders and ensuring public notice of patent claims. Furthermore, this decision will advance fundamental fairness and equity for patent holders and the public, reduce the incentive to litigate collateral issues in patent cases, and promote efficiency in claiming.

\section{BACKGROUND}

The issue raised in WMS Gaming involves two different but somewhat confusingly related concepts within American patent law: means plus function claims and the doctrine of equivalents. Each is fundamentally related to different, and sometimes opposing, policy rationales that underlie the patent system in the United States. ${ }^{11}$ To comprehend the importance of the court's decision in WMS Gaming, then, one must first have a basic understanding of U.S. patent law.

\section{A. Patent Basics}

The courts have long been concerned with the scope of protection afforded by patent claims. The patent system is designed to promote the public good by encouraging invention. ${ }^{12}$ An inventor who is willing to disclose to the public the new device or process he has created is in return granted a temporary right to exclude others from practicing the invention. ${ }^{13}$ This right allows the inventor to prevent others from making, using, offering for sale, selling, or importing the patented invention during the term of the patent. ${ }^{14}$

11. See infra notes $16-33$ and accompanying text.

12. See U.S. CONST. art. I, § 8, cl. 8 ("The Congress shall have Power ... [t] promote the Progress of Science and useful Arts, by securing for limited Times to Authors and Inventors the exclusive Right to their respective Writings and Discoveries.”).

13. See 35 U.S.C. $\$ 154$ (1994).

14. See 35 U.S.C. § 271(a) (1994). The patent grant is frequently characterized as a monopoly on the right to practice the invention. See, e.g., 1 WILLIAM C. ROBINSON, THE LAW OF PATENTS FOR USEFUL INVENTIONS $§ 44$, at 67 (1890) (“[T] he patent privilege is a true 
Because competitors may be prevented from exploiting the subject matter claimed by the patent while it is in force, the patent allows the patent holder, for a limited time, to charge a higher price for the use of the invention than the holder would be able to obtain absent the protection afforded by the patent. ${ }^{15}$

This ability to charge a higher price for the use of the invention for a limited time theoretically promotes scientific progress in three ways. ${ }^{16}$ First, the patent acts as an incentive to invent by ensuring that those who spend their time and money on research and development of new and useful devices or processes will be suitably compensated for their efforts. ${ }^{17}$ Second, the patent acts as an incentive to disclose inventions to the public by preventing commercial competitors of the patent holder from copying the claimed invention without permission. ${ }^{18}$ Finally, the patent acts as an incentive to innovate by encouraging companies to invest whatever resources are necessary to

monopoly, granted in derogation of the common right."). This characterization is arguably erroneous in two regards. First, "the federal patent laws do not create any affirmative right to make, use, or sell anything." Leatherman Tool Group Inc. v. Cooper Indus., Inc., 131 F.3d 1011, 1015 (Fed. Cir. 1997) (restating the black-letter law as enunciated in Bloomer v. McQuewan, 55 U.S. (14 How.) 539, 549 (1852) ("The franchise which the patent grants, consists altogether in the right to exclude every one from making, using, or vending the thing patented, without the permission of the patentee. This is all that he obtains by the patent.")). Second, because the patent gives its owner no right to practice the invention, the patent grant is not truly a monopoly, not even a temporary one. See generally Giles S. Rich, Are Letters Patent Grants of Monopoly?, 15 W. NEW ENG. L. REV. 239 (1993) (tracing the history of patents and monopolies and concluding that the rights conferred by a patent cannot correctly be considered a monopoly). But see Giles Sutherland Rich, My Favorite Things, 35 IDEA 1, 4-5 (1994) (retreating from his prior position and concluding that "[t]he fuel of the patent system is monopoly power").

15. See Rebecca S. Eisenberg, Patents and the Progress of Science: Exclusive Rights and Experimental Use, 56 U. CHI. L. REV. 1017, 1021-22 (1989).

16. See id. at $1024,1036-37$.

17. See id. at 1024-26. Patents may also maximize the value to society of the investments made in a particular area. See Edmund W. Kitch, The Nature and Function of the Patent System, 20 J.L. \& ECON. 265, 276 (1977):

$[\mathrm{T}]$ he potential gains from exclusive ownership are particularly large. No one is likely to make significant investments searching for ways to increase the commercial value of a patent unless he has made previous arrangements with the owner of the patent. This puts the patent owner in a position to coordinate the search for technological and market enhancement of the patent's value so that duplicative investments are not made and so that information is exchanged among the searchers.

18. See Eisenberg, supra note 15, at 1028-30; see also Kitch, supra note 17, at 277 ("Only in the case of a patented product is a firm able to make the expenditures necessary to bring the advantages of the product to the attention of the customer without fear of competitive appropriation if the product proves successful."). 
exploit an already existent and potentially lucrative invention that has not yet been developed to the point of commercial feasibility. ${ }^{19}$

In order that the public will truly benefit from what Thomas Jefferson called "the embarrassment of an exclusive patent," ${ }^{20}$ an inventor applying for a patent must explain the invention in a specification, ${ }^{21}$ including one or more claims that delineate the exact part or combination that he considers to be his invention. ${ }^{22}$ Once the patent issues, it is published by the Patent and Trademark Office (PTO) ${ }^{23}$ thus guaranteeing both disclosure to the general public of the new knowledge the claimed invention represents and public notice of what cannot be used during the patent term without infringing upon the rights of the patent holder. ${ }^{24}$

19. See Eisenberg, supra note 15, at 1036-37 ("These additional investments [getting an invention ready for commercial exploitation] may dwarf the initial research expenditures in making the invention. The protection of a patent monopoly enhances the likelihood that a firm will be willing to undertake these investments.") (footnote omitted); see also Kitch, supra note 17, at 271 ("Many inventions... are patented in a commercially significant form, yet the patented form is trivial in significance as compared to the later derived and improved versions. ... A review of the invention case studies ... shows that the first patentable invention frequently occurs years before the first significant commercial product.") (citation omitted).

This theory, although only rarely relied upon by the courts, see Picard v. United Aircraft Corp., 128 F.2d 632, 643 (2d Cir. 1942), has been offered by numerous commentators as a justification for the patent system. See Eisenberg, supra note 15, at 1037 n.82 (noting how "a patent monopoly is necessary to induce firms to invest in 'innovation'-i.e., putting existing inventions to practical use").

20. See Graham v. John Deere Co., 383 U.S. 1, 9 (1966) (quoting Thomas Jefferson). Jefferson's phrase exemplifies the implicit revulsion with which Americans have typically regarded monopolies of any kind. See id. at 8.

21. See 35 U.S.C. § 111 (1994); id. § 112:

The specification shall contain a written description of the invention, and of the manner and process of making and using it, in such full, clear, concise, and exact terms as to enable any person skilled in the art to which it pertains, or with which it is most nearly connected, to make and use the same, and shall set forth the best mode contemplated by the inventor of carrying out his invention.

See also Autogiro Co. v. United States, 384 F.2d 391, 397 (Ct. Cl. 1967) ("[T]he specification . . describe[s] the manner and process of making and using the patent so that any person skilled in the patent's art may utilize it.").

22. See 35 U.S.C. $\S 112$. The patent specification must "conclude with one or more claims particularly pointing out and distinctly claiming the subject matter which the applicant regards as his invention." Id. The purpose of the claims is not to provide a technical description of the invention but rather to point it out in a way that between distinguishes it from that which was previously known and defines the area protected by the patent. See In re Vamco Mach. \& Tool, Inc., 752 F.2d 1564, 1577 n.5 (Fed. Cir. 1985). Thus, the patent claims are like the metes and bounds in a deed that does not describe the land conveyed but merely defines which parcel it is. See id.

23. See 35 U.S.C. $\$ 153$.

24. See 35 U.S.C. $\$ 154$. 
The scope of protection the claims recited in the patent provide is of vital importance if the patent system is to fulfill its constitutional purpose..$^{25}$ The claims establish the metes and bounds of the right to exclude that are secured by the patent. ${ }^{26}$ In other words, the claims define the scope of protection or coverage. If the courts typically construe patent claim language so literally that the coverage provided is too narrow, then many inventors may be discouraged from obtaining patents and may conceivably either exploit their discoveries in secret $^{27}$ or refrain from investing in expensive research and development efforts. ${ }^{28}$ The courts have expressed concern that because developing new technology is risky and expensive, failure to provide adequate protection for patent owners could harm the American economy.

If the courts typically construe the patent claim language so broadly that the coverage the claims provide to patent holders is nebulous, however, the public notice function served by printing the patent claims will be undermined. ${ }^{30}$ Because other inventors will

25. See U.S. CONST. art. I, $\S 8$, cl. 8 ("The Congress shall have Power ... [t]o promote the Progress of Science and useful Arts, by securing for limited Times to Authors and Inventors the exclusive Right to their respective Writings and Discoveries.").

26. See Vamco Mach. \& Tool, 752 F.2d at 1577 n.5.

27. See Eisenberg, supra note 15 , at 1028.

28. See id. at 1024-25.

29. See Hilton Davis Chem. Co. v. Warner-Jenkinson Co., 62 F.3d 1512, 1529-32 (Fed. Cir. 1995) (Newman, J., concurring), rev'd on other grounds, 520 U.S. 17 (1997). As Judge Newman explained:

Technologic innovation has driven the American economy, over the past century, to the exclusion of virtually all other growth factors. Many students of technologic change have explained that innovative activity is fundamental to industrial vigor, developing new markets while enhancing productivity and competitiveness, thereby strengthening and enriching the nation.... I need not belabor that the economic risk in developing new technology is high, that the potential return must warrant the risk, and that the return must pay for the failures as well as the successes.... The larger public interest requires setting the optimum balance between the purpose of supporting the innovator, in the national interest, and the purpose of supporting improvement and competition, also in the national interest.

Id. (footnote omitted).

30. See London v. Carson Pirie Scott \& Co., 946 F.2d 1534, 1538 (Fed. Cir. 1991):

[I]f the public comes to believe (or fear) that the language of patent claims can never be relied on, and that [protection is regularly extended] beyond the scope of the claims, then claims will cease to serve their intended purpose. Competitors will never know whether their actions infringe a granted patent.

One commentator has suggested that where claim language fails literally to capture additional scope because of the patentee's mere failure to recognize the potential value of one part of an invention, the patentee should not be allowed to reclaim the additional scope through the doctrine of equivalents, because the marginal cost of more careful patent prosecution to a patentee is much less than the cost of resolving confusion about claim language to later 
never be sure exactly what the claim language will be deemed to protect ${ }^{31}$ the public will also be deprived of access to new knowledge because those other inventors will be discouraged from finding parallel but different means for achieving the same result as does the patented invention. ${ }^{32}$ In addition, interpreting the patent claim language too broadly could give the patentee an undeserved windfall that encompasses future technological improvements. ${ }^{33}$

Judicial attempts to apply the patent laws to claim language therefore reflect a continuing struggle to find the appropriate balance between extremely broad interpretations that would overly insulate patent owners from competition or new developments and narrow, literal interpretations that would deter scientific progress because inventors are unable to earn an appropriate return on their investments.

\section{B. Means Plus Function Claims}

One particular area where the courts have struggled to find the appropriate balance is that of means plus function claims. ${ }^{34}$ Although every patent must distinctly claim the invention it seeks to protect, ${ }^{35}$ the patent claims are not required to describe precisely all the elements that make up the invention. ${ }^{36}$ Some patents use a functional rather than structural approach, describing the invention by what it does (its function) rather than what it is. ${ }^{37}$ Many consider these functional expressions, which are sometimes written as "means plus function" claims, the best way to claim inventions in certain

inventors. See Joseph S. Cianfrani, Note, An Economic Analysis of the Doctrine of Equivalents, 1 VA. J.L. \& TECH. 1, 50 (1997).

31. See Carson Pirie Scott, 946 F.2d at 1538 .

32. See Eisenberg, supra note 15, at 1028 n.44; cf. Kitch, supra note 17, at 278 ("After a patent is issued, other firms have an incentive to invent substitute technologies even if the substitute technology is less efficient than the patented technology but can be produced more cheaply than the existing royalty rate.").

33. See Martin J. Adelman et al., Cases and Materials on Patent law 586 (1998)

34. Means plus function claims are also commonly referred to as "112 paragraph sixth" claims, as they are authorized at 35 U.S.C. $\$ 112$, para. 6 of the current United States Code.

35. See 35 U.S.C. $\$ 112$ (1994).

36. See id. para. 6 .

37. See Warner-Jenkinson Co. v. Hilton Davis Chem. Co., 520 U.S. 17, 27 (1997) ("Thus ... an applicant can describe an element of his invention by the result accomplished or the function served, rather than describing the item or element to be used (e.g., 'a means of connecting Part A to Part B,' rather than 'a two-penny nail')."). 
contexts. ${ }^{38}$ The patent statutes obligate the judiciary to ensure that a patent claiming a particular function, rather than describing the elements that accomplish the function, provides enough information to qualify as a true public disclosure of the invention. ${ }^{39}$ Two early courts expressed this concern-in Wyeth v. Stone, ${ }^{40}$ where a patent that claimed "cut[ting] ice of a uniform size, by means of an apparatus worked by any other power than human" was held overly broad, ${ }^{41}$ and in O'Reilly v. Morse, ${ }^{42}$ where Samuel Morse attempted to claim "the use... of the electric... current... for marking or printing intelligible characters, signs, or letters, at any distances." ${ }^{, 4}$

38. See David W. Brownlee, The Scope of Equivalents Under 35 U.S.C. \& 112 If 6 Should Vary Depending on Importance of the Means-Plus-Function Recitation to the Invention as a Whole, 81 J. PAT. \& TRADEMARK OFF. SOC'Y 451, 451 (1999) (describing such patents as "frequently the best, if not the only way, to appropriately cover an invention in its full scope"); Mark D. Janis, Who's Afraid of Functional Claims? Reforming the Patent Law's \& 112, II 6 Jurisprudence, 15 SANTA ClaRA COMPUTER \& High TECH. L.J. 231, 235 \& n.10 (1999) (explaining that functional claims are particularly popular for software-related inventions because the format is considered useful in meeting subject matter eligibility requirements). A patent can be written in functional language without necessarily employing the means plus function format authorized by 35 U.S.C. $\S 112$, para. 6. See In re Ludtke, 441 F.2d 660, 664 (C.C.P.A. 1971) (emphasizing that "there is nothing intrinsically wrong with the use of [functional] claim language"); Locklin v. Switzer Bros., Inc., 299 F.2d 160, 166 (9th Cir. 1961) (upholding the validity of a patent described in functional terms); $c f$. K-2 Corp. v. Salomon S.A.,

191 F.3d 1356, 1363 (Fed. Cir. 1999) (analyzing functional language as a claim limitation).

39. See 35 U.S.C. $\$ 112$, para. 1.

40. 30 F. Cas. 723 (C.C.D. Mass. 1840).

41. Id. at 727. Justice Story wrote:

The specification states: "It is claimed, as new, to cut ice of a uniform size, by means of an apparatus worked by any other power than human. The invention of this art, as well as the particular method of the application of the principle, are claimed by the subscriber" (Wyeth). It is plain, then, that here the patentee claims an exclusive title to the art of cutting ice by means of any power, other than human power. Such a claim is utterly unmaintainable in point of law. It is a claim for an art or principle in the abstract, and not for any particular method or machinery by which ice is to be cut. No man can have a right to cut ice by all means or methods, or by all or any sort of apparatus, although he is not the inventor of any or all of such means, methods, or apparatus.

Id.

42. 56 U.S. (15 How.) 62 (1854).

43. Id. at 112. The last claim of Morse's patent for the telegraph read, in full:

Eighth. I do not propose to limit myself to the specific machinery, or parts of machinery described in the foregoing specification and claims; the essence of my invention being the use of the motive power of the electric or galvanic current, which I call electro-magnetism, however developed for marking or printing intelligible characters, signs, or letters, at any distances, being a new application of that power of which I claim to be the first inventor or discoverer.

Id. The court invalidated the claim:

Indeed, if the eighth claim of the patentee can be maintained, there was no necessity for any specification, further than to say that he had discovered that, by using the motive power of electro-magnetism, he could print intelligible characters at any 
In 1946, the Supreme Court invalidated a patent written in the means plus function format, holding that the patent claims were insufficient to meet the statutory requirement for a full, clear, and concise description of the invention. ${ }^{44}$ In response, when Congress enacted the current Patent Act in 1952, it included the statutory authorization for the language that became 35 U.S.C. $\$ 112$, para. $6 .^{45}$ Section 112, paragraph 6 specifically authorizes inventors to use functional rather than structural descriptions in patent claims. ${ }^{46}$ Congress did restrict the use of functional language in claims, however, ${ }^{47}$ a functional claim is interpreted only to cover the structure disclosed in the patent specification and equivalents of that structure. ${ }^{48}$

The extent to which this statutory restriction should narrow the scope of coverage provided by claims written in means plus function format is still at issue in the courts. ${ }^{49}$ At first, the courts took a rather

\footnotetext{
distance. We presume it will be admitted on all hands, that no patent could have issued on such a specification. Yet this claim can derive no aid from the specification filed. It is outside of it, and the patentee claims beyond it.

Id. at $119-20$.

44. See Halliburton Oil Well Cementing Co. v. Walker, 329 U.S. 1, 9 (1946) ("The language of the claim thus describes this most crucial element in the 'new' combination in terms of what it will do rather than in the terms of its own physical characteristics or its arrangement in the new combination apparatus."). The Supreme Court's objection was not to functional claim language in general, but to its particular application at the "point of novelty." Id. at 8.

45. See Warner-Jenkinson Co. v. Hilton Davis Chem. Co., 520 U.S. 17, 27 (1997) ("Congress enacted $\S 112$, If 6 in response to Halliburton Oil Well Cementing Co. v. Walker, which rejected claims that 'do not describe the invention but use conveniently functional language at the exact point of novelty." (citation omitted)); Valmont Indus., Inc. v. Reinke Mfg. Co., 983 F.2d 1039, 1042 (Fed. Cir. 1993) (citing P.J. Federico, Commentary on the New Patent Act, Preface to 35 U.S.C.A. $\$ 25$ (1954) (Commentary), in support of the claim that $\$ 112$, para. 6 was written in response to Halliburton).
}

46. See 35 U.S.C. $\$ 112$, para. 6 (1994):

An element in a claim for a combination may be expressed as a means or step for performing a specified function without the recital of structure, material, or acts in support thereof, and such claim shall be construed to cover the corresponding structure, material, or acts described in the specification and equivalents thereof.

47. See Valmont Indus., 983 F.2d at 1042 ("The second clause of the new paragraph [35 U.S.C. $\$ 112$, para. 6], however, places a limiting condition on an applicant's use of means-plusfunction language.... This second clause confines the breadth of protection otherwise permitted by the first clause.").

48. See id.

49. See, e.g., Brownlee, supra note 38, at 454 (noting that the limits of section 112, paragraph 6 are still undetermined in several important respects); Janis, supra note 38, at 235-38 (noting that the Federal Circuit has inconsistently applied characteristics of the doctrine of equivalency to 35 U.S.C. $\$ 112$, para. 6). 
generous view of the scope allowed means plus function claims. ${ }^{50}$ When the Federal Circuit addressed the issue in 1985 in D.M.I., Inc. v. Deere \& Co. ${ }^{51}$ it reversed the lower court's determination of noninfringement and held that a functional claim was not limited to the exact structure described in the patent specification. ${ }^{52}$ The court said that while patentees were required to disclose in the specification some enabling means for accomplishing the function set forth in the means plus function claim, "there is and can be no requirement that applicants describe or predict every possible means of accomplishing that function." ${ }^{3}$

By 1991, however, the Federal Circuit had decided that a narrower view was necessary. In Laitram Corp. v. Rexnord, Inc. ${ }^{54}$ the Federal Circuit held that the district court had erred by not comparing the accused conveyor belt to the one disclosed in the specification. ${ }^{55}$ It was insufficient, said the court, to hold that there was patent infringement merely because the accused device had some means that performed the function claimed in the patent. ${ }^{56}$ The narrowing trend continued in Valmont Industries, Inc. v. Reinke Manufacturing Co. ${ }^{57}$ Although the district court found that Reinke had infringed Valmont's patent for an irrigation system that watered the corners of cultivated fields, ${ }^{58}$ the Federal Circuit reversed and held that the statutory language permitting means plus function language had a "string attached." According to the court, the statutory language does not broaden but rather "restricts the coverage of literal claim language." ${ }^{\circ 0}$ The patentee is limited to the exact structure

50. See, e.g., In re Swinehart, 439 F.2d 210, 212-13 (C.C.P.A. 1971) (holding that there "is nothing intrinsically wrong" with defining some part of an invention in functional terms and that functional language does not, "in and of itself, render[] a claim improper").

51. 755 F.2d 1570 (Fed. Cir. 1985).

52. See id. at 1574 ("To interpret 'means plus function' limitations as limited to a particular means set forth in the specification would be to nullify the provision of $\S 112$ requiring that the limitation shall be construed to cover the structure described in the specification and equivalents thereof.").

53. $I d$.

54. 939 F.2d 1533 (Fed. Cir. 1991).

55. See id. at 1536 .

56. See id.

57. 983 F.2d 1039 (Fed. Cir. 1993).

58. See id. at 1041 .

59. Id. at 1042 .

60. Id. "Section 112, If 6 , limits the broad language of means-plus-function limitations in combination claims ...." Id. at 1043-44. 
disclosed in the specification and its structural equivalents, ${ }^{61}$ rather than to any structure that would accomplish substantially the same result. $^{62}$

The Federal Circuit further clarified the scope accorded means plus function claims in In re Donaldson Co. ${ }^{63}$ where it held that "paragraph six applies regardless of the context in which the interpretation of means-plus-function language arises, i.e., whether as part of a patentability determination in the PTO or as part of a validity or infringement determination in a court." ${ }^{64}$ In other words, the means plus function language restricted both the patentee when asserting the patent against an alleged infringer in court and the PTO when determining whether a patent application should be approved. Finally, in B. Braun Medical, Inc. v. Abbot Laboratories, ${ }^{65}$ the Federal Circuit held that where a drawing was included in the patent specification and clearly showed a structure but did not explain how that structure related to the function, the invention was insufficiently disclosed. ${ }^{66}$

Because courts are concerned with the public notice function of patents and with the potential for vague or ambiguous claims that do not properly disclose inventions, patent claims written in functional language, though permitted, are more narrowly construed than claims written in structural terms. Patentees are limited to the exact structure disclosed in the specification and its structural equivalents when claiming infringement and are required to link the function recited in the patent claim to some particular structure disclosed elsewhere in the patent.

\footnotetext{
61. See id. at 1043 .

62. See id. (explaining that despite the use of the word "equivalent" in section 112, "[a] determination of section 112 equivalence does not involve the equitable tripartite test of the doctrine of equivalents"). In other words, one cannot patent a function or a result; one can only patent tangible parts or steps for performing that function or achieving that result.

63. 16 F.3d 1189 (Fed. Cir. 1994).

64. Id. at 1193 .

65. 124 F.3d 1419 (Fed. Cir. 1997).

66. See id. at 1424:

[S]tructure disclosed in the specification is "corresponding" structure only if the specification or prosecution history clearly links or associates that structure to the function recited in the claim. This duty to link or associate structure to function is the quid pro quo for the convenience of employing § 112, If 6.
} 


\section{The Doctrine of Equivalents}

As with means plus function claims, the doctrine of equivalents is a method by which the courts have struggled to balance two competing public policies: on the one hand, giving patent claim language a broader and more protective interpretation encourages invention, but on the other, a narrower, more literal interpretation ensures that the public notice function is served and protects competing products. The doctrine of equivalents is an equitable remedy designed to broaden the protection afforded to patent owners. ${ }^{67}$ The courts created the doctrine of equivalents in the midnineteenth century ${ }^{68}$ after recognizing that a competitor could adopt (or steal) the essence of a patented invention while making enough minor or obvious changes to carry the product outside the literal scope of the patent claims. ${ }^{69}$ Though it does not extend to patent claims, ${ }^{70}$ the doctrine of equivalents extends the protection not otherwise provided by a literal interpretation of the claim language by declaring that a patent is infringed not only when an accused

67. See, e.g., 60 AM. JuR. 2D Patents § 933 (Supp. 2000) (listing law review articles and cases on the doctrine of equivalents). Although the Federal Circuit has on several occasions made explicit statements that the doctrine of equivalents is an equitable remedy, see, e.g., London v. Carson Pirie Scott \& Co., 946 F.2d 1534, 1538 (Fed. Cir. 1991) (referring to the doctrine of equivalents as an "equitable doctrine"); American Home Prods. Corp. v. Johnson \& Johnson, 25 U.S.P.Q.2d 1954, 1956 (1992) ("[T] he doctrine of equivalents is . . . an equitable remedy."), the court has held that the word "equity" as used in the Graver Tank decision refers only to a sense of general fairness. See Hilton Davis Chem. Co. v. Warner-Jenkinson Co., 62 F.3d 1512, 1521 (Fed. Cir. 1995). Therefore, the issue of equivalence does not invoke the traditional equitable powers of the English courts and is decided by the jury. See id.

68. See Winans v. Denmead, 56 U.S. (15 How.) 330, 343 (1853) ("The exclusive right to the thing patented is not secured, if the public are at liberty to make substantial copies of it, varying its form or proportions.").

69. See Graver Tank \& Mfg. Co. v. Linde Air Prods. Co., 339 U.S. 605, 607 (1950):

[C]ourts have also recognized that to permit imitation of a patented invention which does not copy every literal detail would be to convert the protection of the patent grant into a hollow and useless thing. Such a limitation would leave room for-indeed encourage- the unscrupulous copyist to make unimportant and insubstantial changes and substitutions in the patent which, though adding nothing, would be enough to take the copied matter outside the claim, and hence outside the reach of law.

70. See Wilson Sporting Goods v. David Geoffrey \& Assocs., 904 F.2d 677, 684 (Fed. Cir. 1990) ("To say that the doctrine of equivalents extends or enlarges the claims is a contradiction in terms. The claims-i.e., the scope of patent protection as defined by the claims-remain the same and application of the doctrine expands the right to exclude to 'equivalents' of what is claimed.”). 
device contains elements identical to those described by the patent claims but also when it is "equivalent" to the patented device.

Although the courts created and nurtured the doctrine of equivalents, they have struggled to define exactly what an "equivalent" is. In 1950, the U.S. Supreme Court described the doctrine of equivalents in Graver Tank \& Manufacturing Co. v. Linde Air Products Co. ${ }^{72}$ as an inquiry to determine whether the alleged infringing device " "performs substantially the same function in substantially the same way to obtain the same result" as the device claimed by the patent. ${ }^{73}$ Commonly known as the "function-wayresult" or "tripartite" test, this language from Graver Tank embodied the doctrine of equivalents for much of the rest of the century. ${ }^{74}$ Although the function-way-result test seems straightforward theoretically, in practice it proved difficult to apply, ${ }^{75}$ especially in

71. For example, a patent that claimed the use of a fine threaded screw to attach two other elements of the invention could not be circumvented by using a coarse-threaded screw, nail, or rivet. Winans provides a more substantial application of the doctrine. The plaintiff invented and patented a railroad car, shaped like a cone, that distributed loads more effectively than other freight cars of the day and was therefore more economical to operate. See Winans, 56 U.S. (15 How.) at 339. After observing the new design, the defendant produced a similar car, which was octagonal with a pyramidal base. See id. at 340 . Because the patent only claimed cars shaped like the frustum of a cone, there was no literal infringement of the patent even though the defendant had clearly copied the essence of the plaintiff's invention. See id. The Supreme Court held that the patent had been infringed under the doctrine of equivalents. See id. at 343-44.

72. 339 U.S. 605 (1950).

73. Id. at 608 (quoting Sanitary Refrigerator Co. v. Winters, 280 U.S. 30, 42 (1929)). Today the Federal Circuit prefers to use the phrase "insubstantial differences"; that is to say that an accused product infringes under the doctrine of equivalents where "the differences between that which is claimed and its embodiment in the accused composition are insubstantial." Upjohn Co. v. Mova Pharm. Corp., No. 99-1092, 2000 WL 1277666, at*1 (Fed. Cir. Sept. 11, 2000). The differences between the element of the accused product are insubstantial where "the element in the accused composition performs substantially the same function in substantially the same way to obtain substantially the same result as the claimed element." Id. Equivalence is a question of fact to be determined by the jury. See id.

The courts have recognized that the phrase "insubstantial differences" is not particularly helpful. See Warner-Jenkinson Co. v. Hilton Davis Chem. Co., 520 U.S. 17, 40 (1997) ("[T]he insubstantial differences test offers little additional guidance as to what might render any given difference 'insubstantial.'”); Dawn Equip. Co. v. Kentucky Farms Inc., 140 F.3d 1009, 1015-16 (Fed. Cir. 1998) (recognizing the shortcomings of the insubstantial differences test); id. at 1020 (Plager, J., additional views):

However many variations there are in the words we use to describe the criteria by which to determine when something in fact is the "equivalent" of something else, the basic notion of equivalence does not vary. An equivalent is something that is "equal in force or amount," "like in signification or import," [or] "synonymous."

(citations omitted).

74. See ADELMAN ET AL., supra note 33, at 900.

75. See id: 
newly emerging areas such as biotechnology and computer software. ${ }^{76}$ The inability for companies to predict how the doctrine of equivalents might be applied to their own patents or the patents of their competitors arguably inhibited research and development efforts, ${ }^{77}$ and the difficulty led some commentators to argue that the doctrine of equivalents should be abolished altogether. ${ }^{78}$ Others debated whether the doctrine should be applied to the "invention as a whole" or on an "element-by-element" basis.

Initially, the Federal Circuit applied the function-way-result test to the "invention as a whole." " In Hughes Aircraft Co. v. United States, ${ }^{80}$ Hughes claimed the United States had infringed its patented method for controlling the attitude of a geosynchronous satellite. ${ }^{81}$ Hughes had patented a method for controlling a satellite's on-orbit position, ${ }^{82}$ and several elements of the patent were written in means plus function language. ${ }^{83}$ In practice, Hughes claimed a method in

[E]xperience did not refine this standard, but instead demonstrated that its extraordinary vagueness was of scant use in resolving actual infringement cases. Litigants placed vastly different meanings upon the terms "function," "way," and "result," with patentees reading this [sic] terms broadly and accused infringers narrowly.

Id. The apparent simplicity of the tripartite test is thus unfortunately the opposite of the North Carolina motto, "Esse quam videri" ("To be, rather than to seem").

76. See Hilton Davis Chem., 62 F.3d at 1518 ("As technology becomes more sophisticated, and the innovative process more complex, the function-way-result test may not invariably suffice to show the substantiality of the differences.").

77. See Martin J. Adelman \& Gary L. Francione, The Doctrine of Equivalents in Patent Law: Questions that Pennwalt Did Not Answer, 137 U. PA. L. REV. 673, 682-83 (1989):

[U]ncertainty about the scope of patent protection hinders both patent holders and potential defendants from assessing the possible outcome of litigation or from making other business decisions, such as the direction that research and development efforts should take... The uncertainty generated by the doctrine of equivalents frustrates and chills the activities of ... other inventors, who must be concerned about whether their efforts [to "design around" a patent] will be met by an infringement suit based on the amorphous doctrine of equivalents.

(footnote omitted).

78. See, e.g., Warren T. Jessup, The Doctrine of Equivalents, 54 J. PAT. OFF. SOC'Y 248, 270 (1972) ("The doctrine is basically unsound and unfair to the patentee's competitors. Its continued existence is a reproach of the patent bar.").

79. Texas Instruments, Inc. v. United States Int'l Trade Comm'n, 805 F.2d 1558, 1571 (Fed. Cir. 1986).

80. 717 F.2d 1351 (Fed. Cir. 1983).

81. See id. at 1356. A geosynchronous satellite has an orbital period equaling the Earth's rotational period. In other words, the satellite stays at the same point on the horizon as the Earth turns beneath it. See id. at 1352. Pointing the satellite's receivers and antennae requires the ability to control the satellite's attitude, or the direction in which it is facing in space. See id.

82. See id. at 1352-54.

83. See id. at 1355 . The case centered around the meaning of three paragraphs in the first 
which a ground crew would receive position telemetry from the satellite, calculate the time and duration of station-keeping maneuvers that would correct the satellite's attitude, and then command the satellite to fire its maneuvering thrusters at the calculated times. ${ }^{84}$ The government's satellites, on the other hand, used an onboard computer rather than a ground crew to calculate and command the station-keeping maneuvers, and therefore did not transmit data to an external source or receive and respond to control signals from that source. ${ }^{85}$ Comparing the two methods as a whole, the Federal Circuit found that the onboard computer and the ground crew performed substantially the same function in substantially the same way to achieve the same result. ${ }^{86}$ Thus, the government had infringed Hughes's patent under the doctrine of equivalents. ${ }^{87}$

This broad application of the doctrine of equivalents disturbed many, however, who felt that the threat of litigation posed by uncertainty about the scope of subject matter covered by patent claims stifled, rather than promoted, technological advances. Responding to these concerns, a divided Federal Circuit narrowed the doctrine of equivalents in Pennwalt Corp. v. Durand-Wayland, Inc. ${ }^{88}$ Pennwalt owned the patent on a mechanical device with a network of hard-wired electrical components that sorted fruit by color and weight. ${ }^{89}$ The patent claimed a means of continuously indicating the positions of each item on the conveyor belt. ${ }^{90}$ DurandWayland's device also sorted fruit by color and weight, but it used a computer program that stored the data and did not need to track item locations. ${ }^{91}$ The district court compared each element claimed in Pennwalt's patent to an alleged substitute in the Durand-Wayland sorter. It found that because Pennwalt's hard-wired system tracked item locations and Durand-Wayland's computer did not, the two

\footnotetext{
claim, all of which were written in means plus function language. See id. at 1364. For example, paragraph (e) claimed an apparatus comprising a "means disposed on said body [the satellite] for providing an indication to a location external to said body of the instantaneous spin angle position of said body about said axis and the orientation of said axis with reference to a fixed external coordinate system." Id.

84. See id. at 1360-61.

85. See id.

86. See id. at 1366.

87. See id.

88. 833 F.2d 931 (Fed. Cir. 1987) (en banc).

89. See id. at 933.

90. See id. at 938.

91. See id. at 936.
} 
devices did not perform substantially the same function. ${ }^{92}$ Affirming the finding of non-infringement, the Federal Circuit rejected the "invention as a whole" approach and held that the doctrine of equivalents could only be applied on an "element-by-element" basis. ${ }^{93}$ The decision was immediately controversial: the dissent and some commentators argued that the doctrine should not be narrowed and that the majority was improperly overruling Supreme Court precedent, ${ }^{94}$ but other commentators continued to insist that the doctrine had outlived its usefulness and should be abolished altogether, rather than merely limited. ${ }^{95}$

The debate about the proper legal standard was not settled for another decade. In 1997, the Supreme Court again felt the need to address the scope of coverage provided by the doctrine of equivalents, which the Court declared had "taken on a life of its own, unbounded by the patent claims." 96 Observing that a broad application of the doctrine "conflicts with the definitional and publicnotice functions of the statutory claiming requirement, ${ }^{, 97}$ the Court confined its application to an element-by-element comparison of the claimed invention and the accused device..$^{98}$ The Court also invited

\footnotetext{
92. See id. at 935-36.

93. Id. at 935 .

94. See id. at 940 (Bennett, J., dissenting in part):
}

The majority facially retains the historical test set forth in Graver Tank \& Mfg. Co. v. Linde Air Prods. Co. for infringement under the doctrine of equivalents by stating that infringement in such instances may be found if an accused device performs substantially the same overall function or work, in substantially the same way, to obtain substantially the same overall result as the claimed invention. But in practical effect, the majority has eviscerated the underlying rationale of the Graver Tank test by requiring, under the doctrine of equivalents, an exact equivalent for each element of the claimed invention.

(footnote and citations omitted). Some commentators agreed with Judge Bennett that Graver Tank required the "as a whole" approach. See Gary S. Levenson, Note, An Element-By-Element Analysis of the Doctrine of Equivalents in the Court Of Appeals for the Federal Circuit, 38 DraKe L. Rev. 389, 402-04 (1988/1989); Frank S. Molinaro, Note, Pennwalt Corp. v. DurandWayland, Inc.-The Federal Circuit Redefines the Doctrine of Equivalents, 38 DEPAUL L. REV. 787, 808-10 (1989).

95. See, e.g., Ronald D. Hantman, Doctrine of Equivalents, 70 J. PAT. \& Trademark OFF. SOC'Y 511, 550 (1988):

[T] he Pennwalt decision did not go far enough. It should also have retreated from the doctrine of equivalents of Graver Tank. The Graver Tank decision contradicted the previous one hundred years of Supreme Court precedents and the Pennwalt court should have considered it overruled by the last paragraph of Section 112, 35 U.S.C. 112(6), of the Patent Act of 1952.

96. Warner-Jenkinson Co. v. Hilton Davis Chem. Co., 520 U.S. 17, $28-29$ (1997).

97. Id. at 29.

98. See id. at 29-30. 
lower courts, particularly the Federal Circuit, to impose additional limitations that would narrow the application of the doctrine of equivalents. $^{99}$

\section{Application of the Doctrine of Equivalents to Means Plus Function Claims}

Both the doctrine of equivalents and means plus function claims include the notion of "equivalence," caused confusion in the lower courts. ${ }^{101}$ One of the first areas where the Federal Circuit limited the doctrine of equivalents was in its application to claims written in the means plus function format. ${ }^{102}$ In Dawn Equipment Co. v. Kentucky Farms Inc., ${ }^{103}$ Judge Plager signaled that he was willing to clarify matters by placing further restrictions upon the doctrine of equivalents in cases involving means plus function claims. ${ }^{104}$ Shortly thereafter, ${ }^{105}$ a Federal Circuit panel did impose additional restrictions on the application of the doctrine to

99. See id. at 39 n.8.

100. As discussed supra Part II.B, a case of literal infringement of a means plus function or 35 U.S.C. $\S 112$, para. 6 claim is made out when the accused device has a function identical to that claimed by the patent and encompasses structure identical or equivalent to that described in the specification. See 35 U.S.C. $§ 112$, para. 6 (1994). If there is no literal infringement, an accused device may still infringe under the doctrine of equivalents if it is "equivalent" to the claimed device when compared element-by-element using the "insubstantial differences" or "function-way-result" tests. Warner-Jenkinson, 520 U.S. at 39-40.

101. See, e.g., Alpex Computer Corp. v. Nintendo Co., 102 F.3d 1214, 1222-23 (Fed. Cir. 1996) (using the doctrine of equivalents to evaluate the equivalence of two similar, but not identical, products); Valmont Indus., Inc. v. Reinke Mfg. Co., 983 F.2d 1039, 1043 (Fed. Cir. 1993) ("[T]he word 'equivalent' in $\S 112$ should not be confused, as it apparently was here, with the 'doctrine of equivalents."” (quoting D.M.I., Inc. v. Deere \& Co., 755 F.2d 1570, 1575 (Fed. Cir. 1985))).

102. See Jason Schultz, Chiuminatta Concrete Concepts Inc. v. Cardinal Industries, Inc. \& Dawn Equip. Co. v. Kentucky Farms, Inc., 14 BerKeLEY TECH. L.J. 173, 174 (1999).

103. 140 F.3d 1009 (Fed. Cir. 1998).

104. See id. at 1018-22 (Plager, J., additional views). Judge Plager opined:

I believe that the practice of claiming under $\S 112$, If 6 would be much improved if we adhered to the proposition that the "equivalents" of "structure, material, or acts described in the specification" are those found to be within the scope of that term as it is used in $\S 112$, I 6, and not elsewhere. Accordingly, the separate judicially-created doctrine of equivalents would have no application to those aspects of [elements] drawn in means-plus-function form.

Id. at 1021-22 (Plager, J., additional views).

105. Chiuminatta was decided on May 14, 1998, only a few weeks after Dawn Equipment was decided on March 24, 1998. 
means plus function claims in Chiuminatta Concrete Concepts, Inc. v. Cardinal Indus., Inc. ${ }^{106}$

The Chiuminatta pane $^{107}$ created a bright-line rule that the doctrine of equivalents is never available when the alternative structure accused of infringing a means plus function claim is based on technology available at the time the patent was issued. ${ }^{108}$ Judge Lourie asserted that the doctrine of equivalents exists only because the future is unpredictable and technological advances can produce close variants of the structure disclosed in a patent already issued. ${ }^{109}$ Alternative structures based on technology already in existence at the time a patent issued, however, could easily have been disclosed in the original patent specification. ${ }^{110}$ The failure of the patent applicant to disclose such alternative structures, reasoned the panel, leads to the conclusion that the patent holder did not consider them equivalent to the structure disclosed by the patent at the time of issuance and therefore should not be allowed to claim their equivalence in a later infringement proceeding. ${ }^{111}$ Thus, the trend toward restricting the

\footnotetext{
106. 145 F.3d 1303 (Fed. Cir. 1998).

107. The panel included Circuit Judges Lourie, Michel, and Plager. See id. at 1305.

108. See id. at 1310-11. This result reversed the previous practice of the Federal Circuit. In Pennwalt Corp. v. Durand-Wayland, Inc., 833 F.2d 931 (Fed. Cir. 1987) (en banc), the accused device used microprocessor technology available at the time Pennwalt applied for its patent. See id. at 941 n.4 (Bennett, J., dissenting in part). Both the majority and dissent agreed that, had Durand-Wayland merely substituted a microprocessor for Pennwalt's hard-wired circuitry, Pennwalt could have made out an infringement case under the doctrine of equivalents. See id. at 935; id. at 941 n.4 (Bennett, J., dissenting) ("[I]t is clear that an equivalent can be found in technology known at the time of the invention, as well as in subsequently developed technology." (citing Atlas Powder Co. v. E.I. Du Pont De Nemours \& Co., 750 F.2d 1569, 1581 (Fed. Cir. 1984))).
}

109. See Chiuminatta, 145 F.3d at 1310:

The doctrine of equivalents is necessary because one cannot predict the future. Due to technological advances, a variant of an invention may be developed after the patent is granted, and that variant may constitute so insubstantial a change from what is claimed in the patent that it should be held to be an infringement. Such a variant, based on after-developed technology, could not have been disclosed in the patent. Even if such an element is found not to be a $\$ 112$, II 6, equivalent because it is not equivalent to the structure disclosed in the patent, this analysis should not foreclose it from being an equivalent under the doctrine of equivalents.

110. See id. at 1311 ("[G]iven the prior knowledge of the technology asserted to be equivalent, it could readily have been disclosed in the patent.").

\section{See id.}

There is no policy-based reason why a patentee should get two bites at the apple. If he or she could have included in the patent what is now alleged to be equivalent, and did not, leading to a conclusion that an accused device lacks an equivalent to the disclosed structure, why should the issue of equivalence have to be litigated a second time? 
application of the doctrine of equivalents to means plus function claims continued.

\section{WMS GAMING INC. V. INTERNATIONAL GAME TECHNOLOGY $Y^{112}$}

The Federal Circuit soon found another opportunity to refine the application of the doctrine of equivalents to means plus function claims. The U.S. District Court for the Northern District of Illinois held that WMS Gaming literally infringed IGT's patent, and WMS Gaming appealed the ruling. ${ }^{113}$ In the resulting decision, the Federal Circuit would, for the first time, decide how the doctrine of equivalents would apply to means plus function claims when the function claimed in the patent and the function of the allegedly infringing device were only substantially similar, rather than identical.

\section{A. The Facts}

Defendant International Game Technology (IGT) owned United States Patent No. 4,448,419 (the Telnaes patent), which claims a slot machine that appears to be a standard mechanical slot machine but is capable of decreasing the odds of winning. ${ }^{114}$ Unlike standard mechanical slot machines, where the odds are equal that a reel will stop in any given position, the Telnaes slot machine controls the reels electronically to adjust the odds that certain reel stop positions will be selected. ${ }^{115}$ When the machine is played, the control circuitry determines the reel stop position randomly and then stops the reel at that position. ${ }^{116}$ The reel stop position is chosen by selecting a random number from a range greater than the number of stop positions on the reel. ${ }^{117}$ The random numbers are non-uniformly mapped to the reel stop positions; because the range is greater than the number of actual reel stop positions, some reel stop positions are represented by more than one random number. ${ }^{118}$ The non-uniform mapping allows

\footnotetext{
112. 184 F.3d 1339 (Fed. Cir. 1999).

113. See id. at 1342 .

114. See id. at 1342-43.

115. See id. at 1343 .

116. See id.

117. See id.

118. See id. For example, the random number generator could be programmed to choose a number between 1 and 50 where the reel only has 20 reel stop positions. Non-uniform mapping means that some reel stop positions may have only one random number assigned to them, while others may have several. See id.
} 
the machine's owner to decrease the probability, and thus increase the potential payoff, of any particular combination of reel stop positions. ${ }^{119}$ The Telnaes patent is written in means plus function format and claims a slot machine including "means for assigning a plurality of numbers" to stop positions such that at least one stop position is represented by more than one number and "means for randomly selecting one of said plurality of assigned numbers." Telnaes patent discloses a microprocessor or computer as the means of performing the "means for assigning" element and also discloses an algorithm controlling the assignment of numbers to reel stop positions. $^{121}$

Nine years after the Telnaes patent was issued, virtual reel slot machines had become widely accepted in the market, ${ }^{122}$ and plaintiff, WMS Gaming Inc. (WMS), introduced its own version called the WMS $400 .{ }^{123}$ Like the Telnaes invention, the WMS 400 controls the reels electronically to manipulate the odds of winning. ${ }^{124}$ Though the WMS 400 machine also uses a microprocessor or computer to assign random numbers, it is programmed with a different algorithm from the one disclosed in the Telnaes patent. ${ }^{125}$ Rather than determining the reel stop positions and then calculating the resultant payoff, the

119. See id. For example, assume a mechanical slot machine reel has 20 stop positions with 9 cherries, 6 oranges, 4 "lucky number" $7 \mathrm{~s}$, and only one gold bar. On any given pull of the lever, the odds of getting a gold bar on that reel are therefore $1 / 20$, or $5 \%$, and the odds of hitting the jackpot by getting three gold bars-one on each reel-are $(1 / 20) *(1 / 20) *(1 / 20)=1 / 8000$, or $0.0125 \%$. If the same reel were electronically controlled, those odds can be changed drastically. Assume a random-number generator chooses a number between 1 and 50 for each reel. Given non-uniform mapping, random numbers 1 to 5 are mapped to reel stop position 1 (a cherry), 6 to 8 are mapped to reel stop position 2 (another cherry), and so forth. Only random number 50 is mapped to reel stop position 20 - the gold bar. The odds of getting three gold bars, and thus the jackpot, are now $(1 / 50) *(1 / 50) *(1 / 50)=1 / 125,000$, or $0.0008 \%$.

120. Id. at 1346. Both parties agreed that claim 1 controlled the case. See id. Claim 1 reads:

1. A game apparatus, comprising: a reel mounted for rotation about an axis through a predetermined number of radial positions; means to start rotation of said reel about said axis; indicia fixed to said reel to indicate the angular rotational position of said reel; means for assigning a plurality of numbers representing said angular positions of said reel, said plurality of numbers exceeding said predetermined number of radial positions such that some rotational positions are represented by a plurality of numbers; means for randomly selecting one of said plurality of assigned numbers; and means for stopping said reel at the angular position represented by said selected number.

Id. at 1346-47.

121. See id. at 1347-48.

122. See id. at 1343-44.

123. See id. at 1344.

124. See id.

125. See id. at 1350. 
WMS 400 first calculates the payoff and then chooses reel stop positions that represent that payoff. ${ }^{126}$ The WMS 400 calculates the payoff by using a random number generator to select two numbers, mapping the numbers to two payoff multipliers, and then multiplying the payoff multipliers together. ${ }^{127}$ Once the payoff is calculated, a third random number is generated and determines the reel stop positions corresponding to the payoff amount. ${ }^{128}$

After the introduction of the WMS 400, IGT sent WMS a ceaseand-desist letter claiming that the new machine violated the Telnaes patent. ${ }^{129}$ When WMS responded by seeking a declaratory judgment for non-infringement and invalidity in the U.S. District Court for the Northern District of Illinois, IGT counterclaimed for willful infringement. ${ }^{130}$ After a bench trial, the district court held that the Telnaes patent was not invalid and that WMS had willfully infringed the patent both literally and under the doctrine of equivalents. ${ }^{131}$ The court later ordered WMS to pay a damage award, which, after tripling for willful infringement, exceeded $\$ 30$ million. ${ }^{132}$ WMS appealed the judgment of liability. ${ }^{133}$

\section{B. The Holding}

The U.S. Court of Appeals for the Federal Circuit reversed the lower court's finding of literal infringement but affirmed the finding of infringement under the doctrine of equivalents. ${ }^{134}$ The court agreed that there were only insubstantial differences between assigning and selecting combinations of single numbers and assigning and selecting single numbers ${ }^{135}$ and held that an accused device may infringe under the doctrine of equivalents, even when its function is not identical to that disclosed in the patent. ${ }^{136}$

\footnotetext{
126. See id. at 1344.

127. See id.

128. See id.

129. See id. at 1345 .

130. See id.

131. See id. at $1345-46$.

132. See id. at 1345 .

133. See id. at 1346. WMS also appealed the amount of damages and the district court's denial of a new trial, but neither issue is relevant for the purposes of this Note. See id.

134. See id. at 1354.

135. See id. at $1353-54 \&$ n.7.

136. See id. at 1353.
} 


\section{THE WMS GAMING COURT'S ANALYSIS}

Judge Schall, writing for the WMS Gaming panel, ${ }^{137}$ began the court's infringement analysis by noting that all of the disputed claims were written in the means plus function format authorized by 35 U.S.C. $\S 112$, para. $6 .{ }^{138}$ Therefore, a finding of literal infringement would require that "'the accused device ... employ means identical to or the equivalent of the structures, material, or acts described in the patent specification"” and that " [t] $]$ he accused device ... perform the identical function as specified in the claims." "139 The court then proceeded to construe the disputed elements of claim 1, which both parties had acknowledged controlled the issue of infringement. ${ }^{140}$

\section{A. Claim Construction}

The first dispute revolved around exactly what was claimed by the patent language "means for assigning a plurality of numbers representing said angular positions of said reel, said plurality of numbers exceeding said predetermined number of radial positions such that some rotational positions are represented by a plurality of numbers." district court had held that it covered any mathematical method for determining correspondence between the randomly selected numbers and the reel stop positions. ${ }^{142}$ The Federal Circuit panel agreed with WMS that this interpretation was overly broad. ${ }^{143}$ Explaining that once a general purpose computer has been programmed to follow a specific set of instructions it is no longer a general purpose computer but instead a special purpose computer, ${ }^{144}$ the panel held that where a means plus function claim discloses a general purpose computer and a specific algorithm that the computer is programmed to perform, "the

\footnotetext{
137. The panel included Judges Rich, Rader, and Schall. See id. at 1342. Because Judge Rich passed away shortly after oral arguments, only Judges Rader and Schall decided the case. See id. at $1342 \mathrm{n}$.*.

138. See id. at 1347.

139. Id. (quoting Valmont Indus., Inc. v. Reinke Mfg. Co., 983 F.2d 1039, 1042 (Fed. Cir. 1993))

140. See id. at 1346 .

141. Id. at 1347 .

142. See id. at 1348 (citing WMS Gaming Inc. v. International Game Tech., No. 94 C 3062, 1996 WL 539112, at *11 (N.D. Ill. Sept. 20, 1996)).

143. See id.

144. See id. (citing In re Alappat, 33 F.3d 1526, 1545 (Fed. Cir. 1994) (en banc)).
} 
disclosed structure is not the general purpose computer, but rather the special purpose computer programmed to perform the disclosed algorithm." 145 The structure disclosed for the Telnaes patent's "means for assigning," then, was limited to a microprocessor programmed to implement the specific algorithm disclosed in the Telnaes patent. ${ }^{146}$

The second disputed element of claim one involved the "means for randomly selecting one of said plurality of assigned numbers." The court held that the function claimed was randomly selecting one of the numbers assigned by the "means for assigning" discussed above and that the structure disclosed to carry out this function was a microprocessor programmed to generate random numbers. ${ }^{148}$

The last disputed element, the "means for stopping said reel at the angular position represented by said selected number," was at issue only because it depended on the construction of the two previous elements. ${ }^{149}$ Both parties agreed that the claimed function was stopping the reel at the position corresponding to the "means for randomly selecting" element and that the structure disclosed to carry out this function was a brake. ${ }^{150}$

\section{B. Literal Infringement}

Claim construction complete, the court determined that the WMS 400 did not literally infringe claim 1 of the Telnaes patent. ${ }^{151}$ The court began by comparing the structure disclosed in the Telnaes patent to that employed by the WMS $400 .{ }^{152}$ Observing that the structure disclosed in claim 1 of the Telnaes patent as the "means for assigning" element was limited to a microprocessor programmed with the algorithm disclosed in the Telnaes patent and that the WMS 400 used a microprocessor programmed with a different algorithm, the court held that the two structures were not identical. ${ }^{153}$

Because 35 U.S.C. $\S 112$, para. 6 only requires that the structure of an accused device be equivalent to that recited by a means plus

\footnotetext{
145. Id. at 1349 .

146. Id.

147. Id.

148. Id.

149. Id. at 1349 \& n.5.

150. Id. at 1349 .

151. See id. at 1352 .

152. See id. at 1350 .

153. Id. at $1350-51$.
} 
function claim, though, the court compared the two algorithms to determine whether the differences between them were insubstantial. $^{154}$ The Telnaes algorithm identified each reel stop position with a single number randomly selected from a plurality of numbers. ${ }^{155}$ In contrast, the WMS 400 algorithm identified reel stop positions with a combination of single numbers randomly selected from a plurality of combinations of single numbers. ${ }^{156}$ The Federal Circuit panel held that expert testimony that "the difference between assigning and selecting single numbers and assigning and selecting combinations of single numbers is insubstantial" was sufficient to affirm the district court's finding that the two structures were equivalent. $^{157}$

The panel reversed the district court's finding of literal infringement, however, because it held that the function of the WMS 400 microprocessor was not identical to the function recited in the Telnaes patent. ${ }^{158}$ The function claimed by the "means for assigning" and "means for selecting" elements of claim 1 is assigning and selecting single numbers. ${ }^{159}$ The WMS 400, on the other hand, assigns and selects combinations of numbers. ${ }^{160}$ Thus, the WMS 400 "does not perform a function identical to that of claim 1 of the Telnaes patent." ${ }^{161}$ In summary, although the WMS 400 used a microprocessor with a structure equivalent to that disclosed by the Telnaes patent, the WMS 400's microprocessor did not have an identical function as required by 35 U.S.C. $\S 112$, para. 6, and therefore the WMS 400 did not literally infringe claim 1 of the Telnaes patent.

\section{Infringement Under the Doctrine of Equivalents}

Although it found no literal infringement, the Federal Circuit panel affirmed the district court's finding of infringement under the doctrine of equivalents. ${ }^{162}$ Judge Schall observed that even when an accused device does not literally infringe a patent claim, it may still

\footnotetext{
154. See id. at 1351.

155. See id. at 1352.

156. See id.

157. Id. In other words, the district court's finding of insubstantial differences between the accused device and the claimed invention was not clearly erroneous. See id. at 1353.

158. See id. at 1352 .

159. Id. at $1349-50,1352$.

160. See id. at $1344,1352$.

161. Id. at 1352 .

162. See id. at 1354 .
} 
infringe under the doctrine of equivalents "if the differences between the claim and the accused device are insubstantial."163 The district court had found that differences between the use of multiple random numbers and a multistep process of the WMS 400 and the single random number and direct process of selecting a reel stop position claimed by the Telnaes patent were insubstantial. ${ }^{164}$

The panel noted that means plus function claims and the doctrine of equivalents both exist to protect patent holders, with means plus function claims incorporating the notion of structural equivalents into the realm of literal infringement. ${ }^{165}$ Failure to find structure equivalent to that disclosed in a means plus function claim would prevent a contrary finding under the doctrine of equivalents, unless the allegedly infringing structure was based on technological advances developed after the patent was granted. ${ }^{166}$

In this case, however, Judge Schall repeated that the accused device did possess structure equivalent to that disclosed in the means plus function claim. ${ }^{167}$ There was no literal infringement only because the functions of the two devices were not identical. ${ }^{168}$ The panel rejected WMS's arguments that the district court had failed to analyze equivalency on an element-by-element basis and that the accused device did not function in substantially the same way as the claimed invention. ${ }^{169}$ The panel then affirmed the district court's finding of infringement under the doctrine of equivalents, holding

163. Id. at 1352. IGT had presented an expert witness, Jonathan Fry, who testified that there was no substantial difference between assigning and collecting single numbers as opposed to combinations of single numbers. See id.

164. See id. at 1353 .

165. See id. (citing Chiuminatta Concrete Concepts, Inc. v. Cardinal Indus., Inc., 145 F.3d 1303, 1310 (Fed. Cir. 1998)).

166. See id. (quoting Chiuminatta Concrete Concepts, 145 F.3d at 1310).

167. See id.

168. See id. As explained above, literal infringement of a means plus function claim requires that (1) the function of the alleged infringing device be identical to the function claimed in the patent, and (2) the structure of the alleged infringing device be either identical to or equivalent to the structure claimed in the patent. See supra note 100. The district court held that selecting a reel stop position with a single random number is structurally equivalent to selecting a reel stop position with a random combination of single numbers, and the Federal Circuit could discern no clear error in that holding. See id. at 1352. Thus, the second condition for literal infringement was satisfied. See id. at 1353 . The Federal Circuit held that the first condition had not been satisfied, however, because the function of the alleged infringing device is not identical to that which is claimed in the patent: the assignment and selection of combinations of numbers is not identical to the assignment and selection of single numbers. See id. at 1352.

169. See id. at 1353-54. 
that to infringe a means plus function claim under the doctrine of equivalents an accused device and the claimed device need not have identical functions but only substantially the same function. ${ }^{170}$

\section{THE EFFECT OF WMS GAMING ON THE APPLICATION OF THE DOCTRINE OF EQUIVALENTS TO MEANS PLUS FUNCTION CLAIMS}

The WMS Gaming decision clarifies the jurisprudence of the doctrine of equivalents as it relates to patent claims written in means plus function language. ${ }^{171}$ Earlier decisions finding infringement where the function of an accused device was only substantially the same as that claimed by the patent, such as Hughes Aircraft Co. v. United States, ${ }^{172}$ were decided before the courts required element-byelement analysis ${ }^{173}$ and eliminated recourse to the doctrine of equivalents when a device found not to be a structural equivalent under 35 U.S.C. $\S 112$, para. 6 is based on a technology known at the time the patent issued. ${ }^{174}$ As a patent claim element written in means plus function language can often be written in a generic manner to claim also functions insubstantially different from those actually recited in the patent specification, the logic of Chiuminatta would suggest that the doctrine of equivalents would not extend the protection provided by the literal language of the patent. ${ }^{175} \mathrm{By}$ holding instead that there need not be identity of function for infringement to be found under the doctrine of equivalents for a means plus function claim, the WMS Gaming court preserved the traditional understanding of the doctrine that has prevailed at least since Graver Tank: that it exists to protect the patentee from "unimportant and insubstantial changes and substitutions."176

170. See id.

171. Of course, the decision could also be interpreted as a reflection of the differences between inventions in the mechanical and computer software areas. See Tobi Carver Clinton, Infringement and Software Claimed Under 35 U.S.C. \& 112, Il 6: Software Function is the Important Part, 5 VA. J.L. \& TECH. 4, 64 \& n.111 (2000).

172. 717 F.2d 1351 (Fed. Cir. 1983), discussed supra notes 80-87 and accompanying text.

173. See Warner-Jenkinson Co. v. Hilton Davis Chem. Co., 520 U.S. 17, $39-40$ (1997).

174. See Chiuminatta Concrete Concepts, Inc. v. Cardinal Indus., Inc., 145 F.3d 1303, 131011 (Fed. Cir. 1998) (declining to apply the doctrine of equivalents "where the equivalence issue does not involve later-developed technologies").

175. See id. at 1311 ("[G]iven the prior knowledge of the [function] asserted to be equivalent, it could readily have been disclosed in the patent.").

176. Graver Tank \& Mfg. Co. v. Linde Air Prods. Co., 339 U.S. 605, 607 (1950). 
There are several reasons why the WMS Gaming court's decision to preserve the traditional requirement that the function of an accused device need be only substantially the same as, rather than identical to, the function recited in the patent claim strikes an appropriate balance between protecting the rights of patent holders and preserving the public notice function of patent claims. First, the doctrine of equivalents is an equitable remedy, ${ }^{177}$ and allowing it to operate where the accused device has a function substantially the same as that recited in the patent claims is the best way to promote fundamental fairness. Recognizing that in order to do equity, courts must occasionally "temper unsparing logic and prevent an infringer from stealing the benefit of the invention," ${ }^{178}$ the Supreme Court has held for nearly a century and a half that application of the doctrine of equivalents is the appropriate means to accomplish this goal. ${ }^{179}$ It is clearly not fair or equitable that an inventor who has voluntarily disclosed a valuable invention to the public can lose the protection of a patent because of changes that are insubstantial or meaningless but nonetheless evade the literal claims of the patent. ${ }^{180}$ In WMS Gaming, refusal to apply the doctrine of equivalents because the microprocessor in the WMS 400 generated sets of random numbers rather than a single random number would have completely deprived IGT of the value of its patent, "subordinating substance to form" and rendering the patent itself "a hollow and useless thing." 181 Thus, refusal to apply the doctrine of equivalents to a function substantially equivalent to that recited in a patent claim would fail to protect the patentee from the "unintended idea gaps which cannot be satisfactorily filled" during the conversion from physical invention to written patent claims. ${ }^{182}$ The WMS Gaming court realized that fundamental fairness and equity would be promoted by protecting patent claims written in means plus function language from accused devices with substantially equivalent functions.

177. See supra note 67 and accompanying text.

178. Royal Typewriter Co. v. Remington Rand, Inc., 168 F.2d 691, 692 (2d Cir. 1948), quoted in Graver Tank \& Mfg. Co., 339 U.S. at 608.

179. See Warner-Jenkinson v. Hilton Davis Chem. Co., 520 U.S. 17, 29-30 (1997) (affirming the role of the doctrine of equivalents in modern patent doctrine); Graver Tank \& Mfg., 339 U.S. at 607 (providing the seminal discussion of the role and purpose of the doctrine of equivalents); Winans v. Denmead, 56 U.S. (15 How.) 330, 343 (1853) (expounding the doctrine of equivalents to secure inventors their exclusive rights).

180. See Graver Tank \& Mfg., 339 U.S. at 607.

181. Id.

182. Autogiro Co. v. United States, 384 F.2d 391, 397 (Ct. Cl. 1967). 
Second, following the same rule for claims written in either structural or means plus function format simplifies application of the doctrine of equivalents and reduces the incentive to litigate collateral issues. A patent claim written in typical structural language is infringed by any structure falling literally within the claim language, but a patent claim written in means plus function language is infringed only by exact copies of the structure recited in the specification or structural equivalents thereof. ${ }^{183}$ Because the scope of protection afforded structures not recited in a particular patent claim may differ drastically depending on whether it is written in means plus function or structural language, a court's determination that patent language does or does not fall within the ambit of 35 U.S.C. $\S$ 112 , para. 6 can have significant consequences for both the patent owner and the alleged infringer. ${ }^{184}$ Whether particular language should be interpreted as a structural or a means plus function claim is therefore a collateral issue frequently raised in patent infringement cases. ${ }^{185}$ The distinction may seem obvious, but there is neither a rule that the word "means" always indicates a means plus function claim nor a requirement that a means plus function claim include the word "means." ${ }^{186}$ Had the WMS Gaming court held that claims written in means plus function language were infringed solely by accused devices with an identical function while claims written in structural

183. See supra notes 47-48 and accompanying text.

184. See William F. Lee \& Eugene M. Paige, Means Plus and Step Plus Function Claims: Do We Know Them Only When We See Them?, 80 J. PAT. \& Trademark Off. Soc'y 251, 251 (1998).

185. See id. at 252. Lee and Paige have collected a long list of cases involving whether or not a claim involved means plus function language. See id. (citing Cole v. Kimberly-Clark Corp., 102 F.3d 524, 530-31 (Fed. Cir. 1996); York Prod., Inc. v. Central Tractor Farm \& Family Ctr., 99 F.3d 1568, 1574 (Fed. Cir. 1996); Greenberg v. Ethicon Endo-Surgery, Inc., 91 F.3d 1580, 1583 (Fed. Cir. 1996); Laitram Corp. v. Rexnord, Inc., 939 F.2d 1533, 1535-36 (Fed. Cir. 1991); Altech Controls Corp. v. E.I.L. Instruments, Inc., No. CIV.A.H-92-3189, 1997 WL 579179, at *5-6 (S.D. Tex. June 6, 1997); Loral Fairchild Corp. v. Victor Co., 906 F. Supp. 798, 808 (E.D.N.Y. 1995); Fairchild Semiconductor Corp. v. Nintendo Co., 30 U.S.P.Q.2d (BNA) 1657 (D. Wash.), aff'd per curiam, 39 F.3d 1197 (Fed. Cir. 1994)). They also provide evidence that there has been a marked increase in litigation involving means plus function claims. See id. at $251 \mathrm{n} .1$ (analyzing Westlaw database mentions of the means plus function phrase over a 15-year period); see also ADELMAN ET AL., supra note 33, at 670-72 (discussing many of the same cases as Lee and Paige and attempting to draw an appropriate conclusion concerning how functional claims should be recognized).

186. See Cole, 102 F.3d at 530 (affirming the lower court ruling that the claimed "perforation means ... for tearing" is not a means plus function element within the meaning of 35 U.S.C. § 112 (1994)); Lee \& Paige, supra note 184, at 259 (stating that "the use of the word 'means' was not talismanic; claims containing 'means' may not be means-plus-function, and claims not containing 'means' may be means-plus-function"). 
language continued to be infringed by accused devices with merely a substantially similar function, litigants would have a powerful new incentive to debate the proper construction of any claim written in language that could be considered even remotely confusing. The WMS Gaming court simplified application of the doctrine and reduced the incentive to litigate collateral issues by instead holding that the doctrine of equivalents would be applied in the same fashion for both structural and means plus function claims.

Finally, knowledge that the doctrine of equivalents will be applied to the function recited in means plus function claims permits efficiency in claiming. While the Federal Circuit has long held that a patent applicant need not list every possible means for a function recited in the patent claim, ${ }^{187}$ failure to extend the protection of the doctrine of equivalents to the functions recited in means plus function claims would have the effect of forcing applicants to list not only the function they intended to claim for their invention but also every possible variation of that function. In WMS Gaming, the court held that the function claimed by the language "means for selecting" and "means for assigning" was that of selecting and assigning single random numbers, not combinations of random numbers. ${ }^{188}$ Nor would changing the language of the claim to something like "means for randomly selecting $a$ number from said plurality of assigned numbers" have guaranteed that combinations of random numbers would be covered by the claim. ${ }^{189}$ Absent the protection extended by the doctrine of equivalents, the patent would probably have had to include claims for separate functions covering selection of one random number, selection of one combination of random numbers, selection of multiple combinations of random numbers, and selection of similar groups of numbers using any other method of generating non-predetermined numbers, such as chaos functions. ${ }^{190}$ The WMS

187. See D.M.I., Inc. v. Deere \& Co., 755 F.2d 1570, 1574 (Fed. Cir. 1985).

188. WMS Gaming Inc. v. International Game Tech., 184 F.3d 1339, 1352 (Fed. Cir. 1999).

189. North Am. Vaccine v. American Cyanamid Co., 7 F.3d 1571, 1575-76 (Fed. Cir. 1993) (holding that while the words "a" or "an" are generally assumed to mean one or more, in a means plus function claim, the specification must somehow denote that the words are intended to have more than their typical singular meanings).

190. Chaos is not random. See Georgia Institute of Technology School of Physics, What is Chaos?, at http://www.physics.gatech.edu/chaos/tutorial/whatischaos2.htm (last modified Aug. 25, 1999) (on file with the Duke Law Journal); George T. Yurkon, Introduction to Chaos and It's [sic] Real World Applications, at http://www.csuohio.edu/physics/kaufman/yurkon/ 
Gaming court chose to encourage efficiency in claiming, allowing applicants to describe only the intended function of their invention rather than every possible insubstantial variation of that function. The decision in WMS Gaming that the function of an accused device need be only substantially the same as, rather than identical to, the function recited in the patent claim advances fundamental fairness and equity, simplifies application of the doctrine by reducing the incentive to litigate collateral issues, and promotes efficiency in claiming.

\section{CONCLUSION}

In recent years, the judiciary has attempted to strike the appropriate balance between protecting patent holders and ensuring public notice of the scope of protection provided by a patent. The existence of 35 U.S.C. $\S 112$, para. 6, which incorporates notions of structural equivalence into the analysis for literal infringement but does not mention functional equivalence, has caused confusion because of its overlap with the doctrine of equivalents. In response, the circumstances in which the doctrine of equivalence may be applied to claims written in means plus function language have been restricted. By confirming that the doctrine of equivalents does extend to claims written in means plus function language when the allegedly infringing device performs only substantially the same function as is recited in the patent claim, the Federal Circuit has halted the trend toward more restrictions at an appropriate point and thereby ensured that the patent grant will continue to provide meaningful protection from infringement.

chaos.html (May 28, 1997) (on file with the Duke Law Journal). A slot machine could easily be programmed to decrease the odds of winning and thereby increase the payoff using chaos functions. 